\title{
Protective impact resistant composite materials based on aluminium-silicate glass-ceramics
}

\author{
O.V.Savvova, G.K.Voronov, O.V.Babich, \\ V.L.Topchiy, O.I.Fesenko, V.D.Tymofieiev \\ National Technical University "Kharkiv Polytechnic Institute", \\ 2 Kyrpychova Str., 61002 Kharkiv, Ukraine
}

Received July 2, 2018

\begin{abstract}
Protective impact-resistant composite materials have been synthesized and the perspectivity of their use as part of impact-resistant structures has been established. Were developed composite materials based on aluminium-silicate glass-ceramic materials and fillers - silicon carbide and zirconium oxide stabilized with yttrium oxide. Are established the effect of the type and content of fillers on the formation of the structure of glass-ceramic materials in correlation with their strength properties. Were obtained the samples of impact-resistant composite materials with high performance properties based on high-strength aluminium-silicate glass-ceramics in conditions of low-temperature two-stage heat treatment, which can be used as a basis for the development of protective structure elements.
\end{abstract}

Keywords: aluminium-silicate glass-ceramic materials, zirconium dioxide, silicon carbide, two-stage heat treatment, impact-resistant.

Синтезированы защитные ударопрочные композиционные материалы и установлена перспективность их применения в составе защитных конструкций. Разработаны составы композиционных материалов на основе стеклокерамических алюмосиликатных материалов и наполнителей - карбида кремния и диоксида циркония, стабилизированного оксидом иттрия. Установлено влияние вида и содержания наполнителей на формирование структуры стеклокерамических материалов во взаимосвязи с их прочностными свойствами. Получены образцы ударопрочных композиционных материалов на основе высокопрочной алюмосиликатной стеклокерамики в условиях низкотемпературной двухступенчатой термообработки с высокими эксплуатационными свойствами, которые могут быть использованы в качестве основы для разработки композиционных защитных элементов.

Захисні ударостійкі композиційні матеріали на основі алюмосилікатної склокераміки. О.В.Саввова, Г.К.Воронов, О.В.Бабіч, В.Л.Топчий, О.І.Фесенко, В.Д.Тилофєєв.

Синтезовано захисні ударостійкі композиційні матеріали та встановлено перспективність їх застосування у складі захисних конструкцій. Розроблено склади композиційних матеріалів на основі склокерамічних алюмосилікатних матеріалів та наповнювачів - карбіду кремнію та діоксиду цирконію стабілізованого оксидом ітрію. Встановлено вплив виду та вмісту наповнювачів на формування структури склокерамічних матеріалів у взаємозв'язку з їх міцносними властивостями. Одержані зразки ударостійких композиційних матеріалів на основі високоміцної алюмосилікатної склокераміки в умовах низькотемпературної двостадійної термічної обробки мають високі експлуатаційні властивості та можуть використовуватися як основа при розробці композиційних захисних елементів. 


\section{Introduction}

Today, the high priority task is to create new polyfunctional materials, and one of the main directions of which is to obtain highly effective protective impact-resistant functional materials. The accumulated longterm experience in the production and utilization of impact-resistant barrier constructions with ceramic elements shows the effectiveness of their use, and provided that the kinetic energy of impact does not exceed $2.0 \div 2.5 \mathrm{~kJ}[1]$. Companies which manufactured of impact-resistant materials most often use ceramic materials based on boron carbide and silicon carbide, in particular, modified by additives of eutectic compositions [2], as well as aluminum oxide or materials based on them. However, the complexity of the production technology and the high price of ceramic raw materials prompts developers and manufacturers to conduct research in the direction of creating alternative high-strength materials with high impact resistance. In this regard, glass-ceramic materials are of particular interest due to the unique ability to combine high mechanical properties with low density, affordable cost and good adaptability, as well as high-strength. So today, shock-resistant materials with a content of highstrength crystalline phases, such as lithium disilicate, spodumene, cordierite, and anorthite, are widely known [3-5].

For a long time, the development of high-strength ceramic-matrix composites based on glass-ceramic matrices was a priority in the creation of aerospace technology products, operated at temperatures up to $1800^{\circ} \mathrm{C}$ in oxidizing conditions [6]. Significant results in this direction have been achieved at the Institute of Aviation and Space Technologies (Japan), by the companies Ube Industry, Nippon Carbon (Japan), Dow Corning and Kaiser (USA). Composite materials based on glass-ceramic matrices in the systems $\mathrm{Li}_{2} \mathrm{O}-\mathrm{Al}_{2} \mathrm{O}_{3}-\mathrm{SiO}_{2}, \mathrm{CaO}-\mathrm{Al}_{2} \mathrm{O}_{3}-$ $\mathrm{SiO}_{2}, \quad \mathrm{BaO}-\mathrm{Al}_{2} \mathrm{O}_{3}-\mathrm{SiO}_{2}, \quad \mathrm{SrO}-\mathrm{Al}_{2} \mathrm{O}_{3}-\mathrm{SiO}_{2}$, which are reinforced with $\mathrm{SiC}$ fibers (Nicolon, Hi-Nicolon) are characterized by strength up to $1000 \mathrm{MPa}$, Young's modulus up to $160 \mathrm{GPa}$ and operating temperature up to $1250^{\circ} \mathrm{C}$ [6]. The main crystal phases of glass-ceramic matrices can be represented by spodumene, triclinic anorthite, monoclinic celzian and strontium anortite. However, the low hardness and crack resistance of given glass-ceramic materials significantly limit their use as impact-resistant components of protective structures. The solution to this problem is the creation of protective impact-resistant composite materials based on aluminium-silicate glass-ceramic with a reduced weight and low cost.

\section{Purpose and methods of research}

The purpose of this work is to developing of impact-resistant composite materials based on aluminium-silicate glass-ceramic with fillers under conditions of low-temperature heat treatment.

For the mixture manufacturing in glass synthesis used natural mineral raw materials (silica, zircon, chalk, potassium feldspar), alumina, pure oxides $\left(\mathrm{ZnO}, \mathrm{TiO}_{2}\right.$, $\mathrm{CeO}_{2}, \mathrm{MgO}$ ) and other chemical substances (boric acid, strontium carbonate, ammonium phosphate). Glasses of the SL and SP series were melted in corundum crucibles in a laboratory electric furnace with carborundum heaters at a temperature of 1250$1450^{\circ} \mathrm{C}$ for $6 \mathrm{~h}$, followed by cooling on a metal plate. Glasses of the CGC series were synthesized at temperatures of $1550 \div 1600^{\circ} \mathrm{C}$ in corundum crucibles in an electric furnace with molybdenum disilicide heaters with gradual cooling in the furnace for $12 \mathrm{~h}$.

Composite materials were obtained on the basis of lithium-aluminum-silicate and magnesium-aluminum-silicate glass-ceramics and fillers of zirconium dioxide stabilized with yttrium (mark DCIZ, TU3442000) or silicon carbide (mark 54C, TU U 24.100222226-059:2006) in the amount of $5 \div$ 10 wt. parts per 100 wt. parts of glass. Grinding of the mixture was carried out in a laboratory planetary mill until rest on a sieve No.125 up less 0,5\%. The fractional composition of glass powders was represented by particles of size $63 \div$ $125 \mu \mathrm{m} \approx 70$ vol. $\%, 25 \div 63 \mu \mathrm{m} \approx 15$ vol. $\%,<25 \mu \mathrm{m} \approx 15 \mathrm{vol}$. $\%$. The size of fractions and their ratios were selected based on calculated data to ensure high packing density of materials.

The presence of the crystalline phase was established using XRD analysis, which was carried out on "DRON-3" apparatus. The study of phase transformations in glasses was carried out with differential thermogravimetric curves, which were obtained using a derivatograph Paulik-Paulik-Erday Q-1500D. A petrographic study was conducted using an NU-2E optical polarization microscope. Vickers hardness (HV) and fracture toughness index (fracture toughness) 
(K1C) were determined using the TMB-1000 device by indenting the Vickers pyramid with a load on the pyramid of $5000 \mathrm{~g}$ by 10 measurements. Impact toughness $(K C U)$ was determined according to GOST (GOST) 11067-2013 (EN1288-1:2000).

\section{Results and discussion}

3.1. The choice of technological methods to providee the impact resistance of glass-ceramics

Important indicators of the impact resistance of research materials are their hardness, strength and crack resistance index, which can be significantly increased as a result of using a number of technological methods, namely:

- when implementing the technology of glass-ceramic materials - by directional orientation of high-strength crystals, which is achieved in the process of directional crystallization of glasses with special composition by creating a temperature gradient;

- when using the technology of composite materials - reinforcement of glass-ceramics with $\alpha-S i C$ fibers for dissipating energy near the crack tip, and reinforcement by particles of tetragonal $\mathrm{ZrO}_{2}$ due to transformational strengthening $[7,8]$.

However, the use of $\mathrm{SiC}$ in the preparation of composite glass-ceramic materials under conditions of exposure to high temperatures in an oxidizing atmosphere is limited by the ability of $\mathrm{SiC}$ in passive and active oxidation [9]. The advantages of a glass-ceramic matrix based on aluminiumsilicate glasses is that the formation of composite material preform occurs at relatively low temperatures and reduces the possibility of strength decrease due to oxidation of SiC. A study of the microstructure of the fiber/matrix interface revealed the presence of a thin carbon layer typical for glass-ceramic composites reinforced with SiC fibers [10].

High impact resistance of composite materials based on aluminium-silicate glass-ceramics is achieved through structural transformation by providing a phase separation process followed by oriented submicron crystallization of the amorphous matrix and its reinforcement with $\mathrm{ZrO}_{2}$ and $\mathrm{SiC}$ phases with the formation of an enhanced crystalline structure during low temperature heat treatment. It is during low-temperature crystallization that glass automatically "chooses" at first those metastable crystalline phases that are most easily wetted by glass, and, as a result, are most stable bond with glass. At long-term high-temperature influence, recrystallization occurs in stable phases, the presence of which will ensure the necessary functional properties of glassceramic materials $[11,12]$.

An important factor under creating composite materials consisting of liquid and solid phases is to ensure the most high density packing of solid particles in a given volume. The highest packing are achieved for variable grain compositions, which contain different size fractions.

The implementation of these technological methods, which were used in this work, will significantly improve the impact resistance of composite materials based on aluminium-silicate glass ceramics.

3.2. Development of composite materials based on aluminium-silicate glass-ceramics and study of the influence of their structure on operational properties

As a basis for the development of composite materials, research glasses were selected, which were previously synthesized by the authors in the systems $\mathrm{Li}_{2} \mathrm{O}-\mathrm{Al}_{2} \mathrm{O}_{3}-\mathrm{SiO}_{2}$ (L-A-S) (series SL and SP) [13], $\mathrm{MgO}-\mathrm{Al}_{2} \mathrm{O}_{3}-\mathrm{SiO}_{2}$ (M-A-S) (series CGC) [14] in the crystalliza-tion field of high-strength phases: a series of SL lithium disilicate; SP series $-\beta$-spodumene; series CGC - mullite.

According to the results of previous investigations were optimized compositions of basic glasses and chosed the impact-resistant glass-ceramic materials SL-9, SP-10, CGC-10 with a certain content of phaseforming components, crystallization catalysts and modifying additives (Table 1), which are characterized by high values of performance characteristics.

Glass-ceramic material SL-9 was synthesized on the basis of glass in the system $\mathrm{Li}_{2} \mathrm{O}-\mathrm{Al}_{2} \mathrm{O}_{3}-\mathrm{SiO}_{2}$ with addition of crystallization catalysts $\mathrm{P}_{2} \mathrm{O}_{5}, \mathrm{ZnO}, \mathrm{ZrO}_{2}$ and modifying components $\mathrm{K}_{2} \mathrm{O}$ and $\mathrm{MgO}$ according to the following heat treatment mode: melting temperature $-1250^{\circ} \mathrm{C}$; annealing mode $-450^{\circ} \mathrm{C}$ for $0.5 \mathrm{~h}$; the first stage (I st.) is $600^{\circ} \mathrm{C}$ for $2 \mathrm{~h}$, the second stage (II st.) is $900^{\circ} \mathrm{C}$ for $0.5 \mathrm{~h}$; forming by slip casting.

Glass-ceramic material SP-10 was synthesized on the basis of glass in the system $\mathrm{Li}_{2} \mathrm{O}-\mathrm{Al}_{2} \mathrm{O}_{3}-\mathrm{SiO}_{2}$ with addition of crystallization catalysts $\mathrm{P}_{2} \mathrm{O}_{5}, \mathrm{ZnO}, \mathrm{ZrO}_{2}, \mathrm{TiO}_{2}$, $\mathrm{CeO}_{2}, \mathrm{SnO}_{2}$ and modifying components $\mathrm{MgO}$ and $\mathrm{K}_{2} \mathrm{O}, \mathrm{CaO}, \mathrm{B}_{2} \mathrm{O}_{3}$ according to the following heat treatment: melting temperature $1450^{\circ} \mathrm{C}$; heat treatment: the first stage (I st.) $-530^{\circ} \mathrm{C}$, respectively, during $2 \mathrm{~h}$, the second stage (II st.). $-850^{\circ} \mathrm{C}$ for $2 \mathrm{~h}$; forming by slip casting. 
Table 1. Chemical composition of research glasses and temperature of their synthesis

\begin{tabular}{|c|c|c|c|c|c|c|c||}
\hline \hline Marks & \multicolumn{3}{|c|}{$\begin{array}{c}\text { Phase-forming } \\
\text { components, wt. } \%\end{array}$} & $\begin{array}{c}\text { Crystallization catalysts, } \\
\text { wt. \% }\end{array}$ & $\begin{array}{c}\text { Modificative additives, } \\
\text { wt. \% }\end{array}$ & $\begin{array}{c}\text { Synthesis } \\
\text { temperature, }\end{array}$ \\
\cline { 2 - 5 } & $\mathrm{Li}_{2} \mathrm{O}$ & $\mathrm{MgO}$ & $\mathrm{Al}_{2} \mathrm{O}_{3}$ & $\mathrm{SiO}_{2}$ & & & \\
$\mathrm{SL}-9$ & 15.0 & - & 3.0 & 65.0 & $\Sigma\left(\mathrm{P}_{2} \mathrm{O}_{5}, \mathrm{ZnO}, \mathrm{ZrO}_{2}\right)=15$ & $\mathrm{~K}_{2} \mathrm{O}=2$ & 1350 \\
$\mathrm{SP}-10$ & 7.0 & 1.0 & 18.0 & 60.0 & $\begin{array}{c}\Sigma\left(\mathrm{P}_{2} \mathrm{O}_{5}, \mathrm{ZnO}, \mathrm{ZrO}_{2}, \mathrm{TiO}_{2},\right. \\
\left.\mathrm{CeO}_{2}, \mathrm{SnO}_{2}\right)=9.5 \\
\Sigma\left(\mathrm{K}_{2} \mathrm{O}, \mathrm{CaO}, \mathrm{B}_{2} \mathrm{O}_{3}\right)=4.5\end{array}$ & 1450 \\
CGC-10 & - & 9.0 & 29.0 & 51.0 & $\begin{array}{c}\Sigma\left(\mathrm{TiO}_{2}, \mathrm{ZrO}_{2}, \mathrm{CeO}_{2},\right. \\
\left.\mathrm{P}_{2} \mathrm{O}_{5}\right)=6\end{array}$ & $\Sigma\left(\mathrm{SrO}, \mathrm{B}_{2} \mathrm{O}_{3}\right)=5$ & 1550 \\
\hline
\end{tabular}

Glass-ceramic material KSK-10 was synthesized on the basis of glass in the system $\mathrm{MgO}-\mathrm{Al}_{2} \mathrm{O}_{3}-\mathrm{SiO}_{2}$ in the presence of crystallization catalysts $\mathrm{TiO}_{2}, \mathrm{ZrO}_{2}, \mathrm{CeO}_{2}, \mathrm{P}_{2} \mathrm{O}_{5}$ and modifying components $\mathrm{SrO}, \mathrm{B}_{2} \mathrm{O}_{3}$ according to the following mode: melting temperature $1600^{\circ} \mathrm{C}$; heat treatment: I st. $850^{\circ} \mathrm{C}$ and II st. $-1150^{\circ} \mathrm{C}$, during $5 \mathrm{~h}$ at each stage; slip casting.

The study of the glasses structure after heat treatment made it possible to establish that for aluminium-silicate glasses SL-9 and SP-10 is typical the process of volume crystallization of glass with formation of lithium disilicate crystals and $\beta$-spodumene crystals, respectively, in the amount of 80 vol. $\%$.

For CGC-10 sample, as the primary crystalline phase are observed solid solutions with a quartz structure under the low-temperature crystallization mode, in the temperature range $850-900^{\circ} \mathrm{C}$. The formation of solid solutions on the $\alpha$-cordierite basis occurs due to the chemical interaction between spinel and $\alpha$-cristobalite at temperatures over $1000^{\circ} \mathrm{C}$. For CGC-10 material the formation of a solid oriented structure were observed under conditions of two-stage heat treatment. Formation such structure type for developed glass-ceramic materials allows for their high mechanical and thermal properties and low density (Table 2).

On the basis of aluminium-silicate glassceramics and fillers - silicon carbide (SC) and zirconium dioxide stabilized by yttrium oxide (ZD), were obtained composite materials marked SL-9-SC, SP-10-SC, CGC-10-SC, SL-9-ZD, SP-10-ZD and CGC-10-ZD.

For composite materials, the addition of $\alpha-\mathrm{SiC}$ and $\mathrm{ZrO}_{2}$ refractory fillers insignificantly shifts the peaks in the thermograms to higher temperatures as the result of the appearance of the first crystalline phases. When the temperature rises to the temperature of appearance of the main crystal phases of this process is not observed. The addition of zirconium dioxide as a crystallization catalyst is an additional factor in increasing the quantity and size of crystals. The high and narrow peaks of exo-effects on thermograms for materials SL-9-ZD-5 (Fig. 1a), SP-10-ZD-5 (Fig. 1b) and CGC-10-ZD-5 (Fig. 1c) indicate the formation submicron crystal structure with the subsequent flow of volume crystallization under increasing temperature with greater intensity than the output glass (Fig. 1). With the addition of 10 wt. $\% \mathrm{ZrO}_{2}$ in the composition of glassceramic materials, the peaks of the exo-effect become more gentle, which may increase the size of the crystals and may lead

Table 2. Physical-chemical properties of research glass-ceramic materials and fillers

\begin{tabular}{||c|c|c|c|c||}
\hline \multirow{2}{*}{ Research materials } & \multicolumn{5}{|c|}{ Properties } \\
\cline { 2 - 5 } & $\alpha \cdot 10^{7},{ }^{\circ} \mathrm{C}^{-1}$ & $H V, \mathrm{GPa}$ & $K_{1 C}, \mathrm{MPa} \cdot \mathrm{m}^{1 / 2}$ & $\rho, \mathrm{g} / \mathrm{cm}^{3}$ \\
\hline \multicolumn{5}{|c|}{ Glass-ceramic materials } \\
\hline SL-9 & 90.00 & 8.82 & 3.15 & 2.40 \\
$\mathrm{SP}-10$ & 21.50 & 8.90 & 3.40 & 2.45 \\
$\mathrm{CGC}-10$ & 54.00 & 10.40 & 3.50 & 2.80 \\
\hline \multicolumn{5}{|c|}{ Fillers } \\
\hline $\mathrm{SiC}$ & 40.00 & $22.3 \div 22.4$ & $3.0 \div 5.23$ & $3.12 \div 3.28$ \\
$\mathrm{ZrO}_{2}\left(\mathrm{Y}_{2} \mathrm{O}_{3}\right.$-stab.) & $50.00 \div 60.00$ & 12.00 & $9.00 \div 10.00$ & 6.00 \\
\hline
\end{tabular}



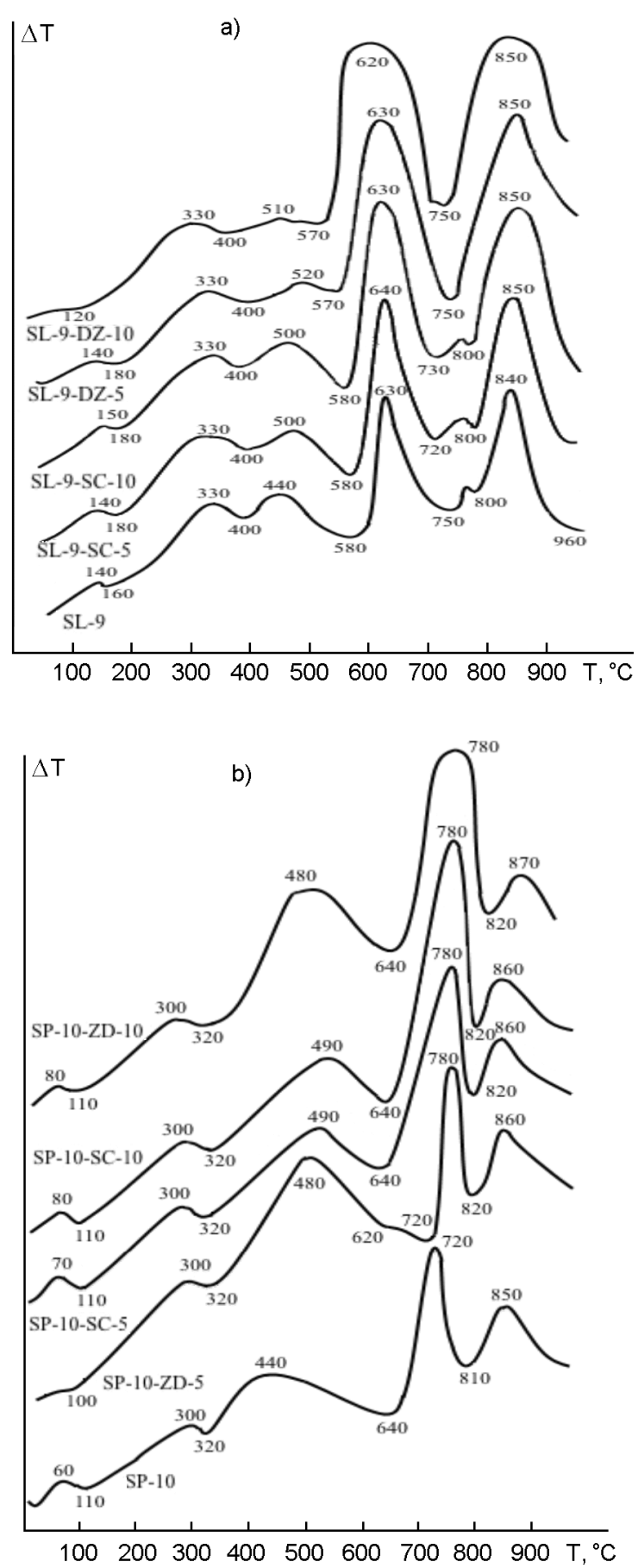

to weakening of crystal structure. For composite materials with the content of $\alpha-S i C$ 5 wt. \% SL-9 -SC-5 (Fig. 1a), SP-10-SC-5 (Fig. 1b) and CGC-10-SC-5 (Fig. 1c) and 10 wt. \% SL-9-SC-10 (Fig. 1a), SP-10-SC-10 (Fig. 1b) and CGC-10-SC-10 (Fig. 1c) there is a similar trend of increasing the volume of the main crystalline phase to 85 vol.\% when compared with the original glass-ceramic materials. However, the structure of

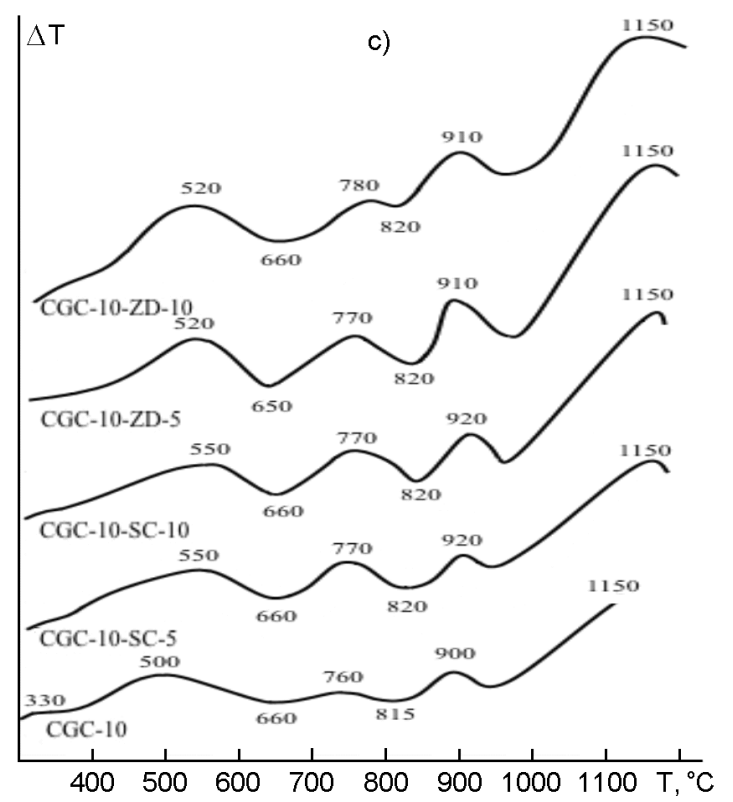

Fig. 1. Thermograms of research composite materials from different series: a) SL; b) SP; c) CGC. composite materials with a content of 10 wt. $\%$ of $\alpha-S i C$ is micronized, as evidenced by the rapid growth of the thermogram curve in the crystallization region.

The study of the composite materials structure made it possible to establish the presence of dense packing of small columnar prismatic crystals of lithium disilicate for materials SL-9-SC-10 (Fig. 2a), $\beta$-spodumene SP-10-SC-10 (Fig. 2b) and short-prismatic 


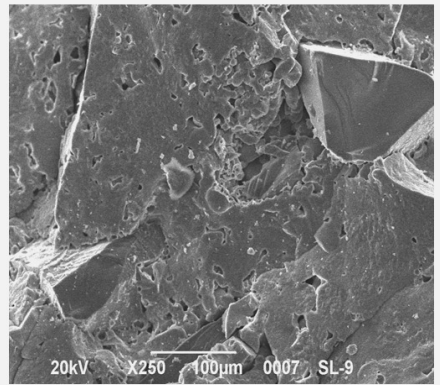

a)

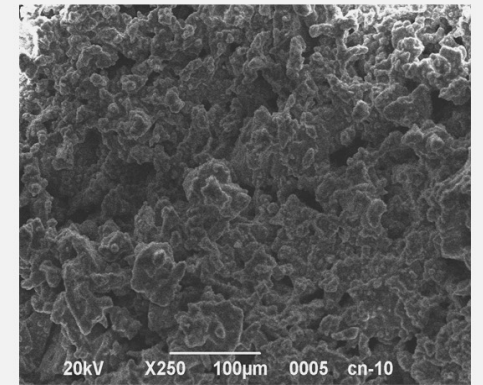

b)

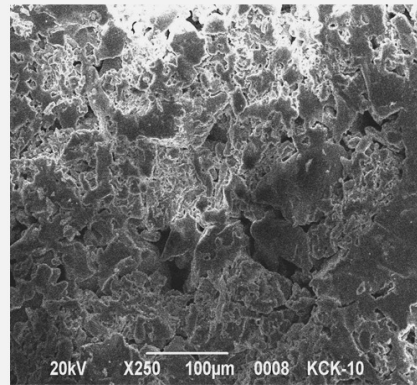

c)

Fig. 2. Structure of developed composite materials: a - SL-9-SC-10; b - SP-10-SC-10; c CGC-10-SC-10.

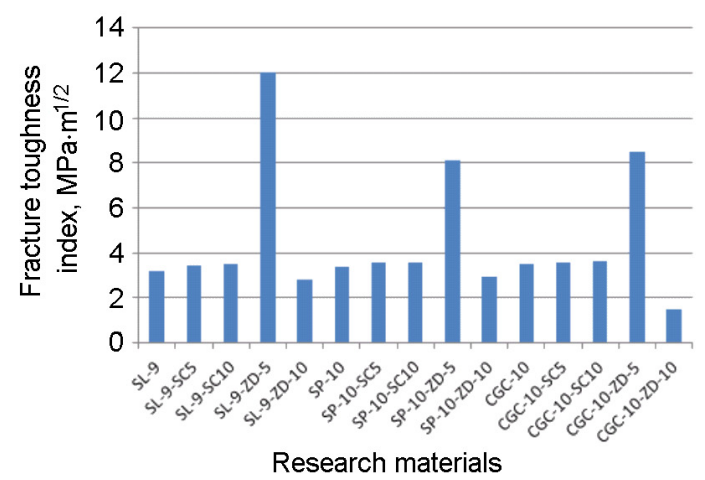

a)

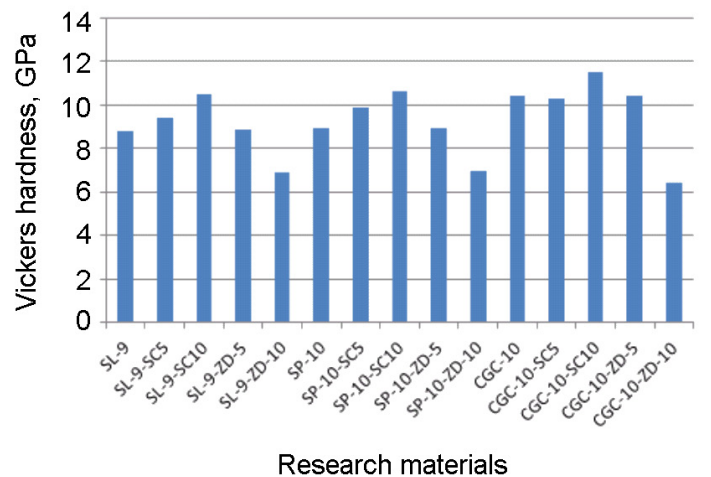

b)

Fig. 3. Mechanical properties of developed composite materials: a $-K_{1 C}, \mathrm{MPa} \cdot \mathrm{m}^{1 / 2}$; b $-H V$, GPa.

mullite crystals for material CGC-10-SC-10 (Fig. 2c), which are arbitrarily oriented and strengthen the material structure. The presence of $\alpha-S i C$ grains with a size of $\approx 90 \mu \mathrm{m}$ with blunt ends, which are melted by glass rims in the composite structure, contribute to blocking the crack due to its deflection or branching.

The mechanical properties of the developed composite materials with a fillers content of 5 or 10 wt. \% generally grow, however, with different intensities (Fig. 3). The largest increase in fracture toughness $\left(K_{1 C}\right)$ is observed for the composite material SL-9$\mathrm{ZD}-5$ with a content of $\mathrm{ZrO}_{2} 5 \mathrm{wt}$. $\%$. Addition the specified filler of 10 wt. $\%$ in the composition of SL-9-ZD-10, SP-10-ZD-10 and CGC-10-ZD-10 sharply reduces $K_{1 C}$ and Vickers hardness $(H V)$, especially for the latter material, as a result of the growth of mullite crystals growing with zirconium dioxide under conditions of prolonged heat treatment at $1150^{\circ} \mathrm{C}$. For compositions with a silicon carbide content, $K_{1 C}$ is increases slightly, while $H V$ increases with considerable intensity with growing content of $\alpha-S i C$ filler from 5 to 10 wt. \% Therefore, the introduc- tion to the composition of composite materials of $\mathrm{ZrO}_{2} 5 \mathrm{wt}$. $\%$ is an important factor for increasing their crack resistance. With the addition of 5 and 10 wt. $\% \alpha-S i C$, is observed an increase the hardness of the developed composite materials (Table 2).

Among the developed materials, the high impact toughness is characterized the composition CGC-10-SC-10 $\left(6.0 \mathrm{~kJ} / \mathrm{m}^{2}\right)$, for materials SL-9-SC-10 and SP-10-SC-10, this factor somewhat decreases up to $\approx 5.7 \mathrm{~kJ} / \mathrm{m}^{2}$. With the addition of zirconium dioxide, due to a slight increase in hardness, the impact strength for materials CGC10-ZD-5, SL-9-ZD-5 and SP-10-ZD-5 is slightly lower $-5.8,5.6,5.6 \mathrm{~kJ} / \mathrm{m}^{2}$, respectively.

Thus, on the basis of the conducted research, have been developed the following technological principles, which are implemented in the development of impact-resistant composite materials:

- ensuring closely-packed structure of the material are possible in the presence of fractions with a size of $63 \div 125 \mu \mathrm{m}$ 
$\approx 70$ vol. $\%$, C $25 \div 63 \mu \mathrm{m}-15$ vol. $\%$, $<25 \mu \mathrm{m}-15 \mathrm{vol} \%$;

- formation of sub-micron oriented interpenetrating glass-ceramic structure of the material in the conditions of low-temperature heat treatment are possible with the presence of high-strength crystal phases of lithium disilicate, $\beta$-spodumene or mullite in the amount of $\approx 85 \mathrm{vol} . \%$;

- blocking of cracks and increase of hardness due to material restructuring during the composite formation are possible with the addition of 5 wt. $\% \mathrm{ZrO}_{2}$ or 10 wt. $\% \alpha-\mathrm{SiC}$.

Studies have shown the promising use of the developed materials based on aluminium-silicate glass-ceramics as protective, impact-resistant composite materials.

\section{Conclusions}

The importance of creating a new type of protective impact-resistant composite materials and their prospects for use in protective structures is established. Were substantiated the choice of technological methods to ensure high impact-resistance of glass-ceramics materials.

Compositions of new type composite glass-ceramic materials based on aluminium-silicate glass-matrix and fillers yttrium-stabilized zirconium dioxide and silicon carbide have been developed. The influence of the type and content of fillers on the formation of the structure of glass-ceramic materials in conjunction with their strength properties has been established and the technological principles for impact-resistant composite materials creation have been developed.
It is shown that the developed impact-resistant composite materials based on highstrength glass-ceramics with a content of 5 wt. $\% Z_{2} r_{2}$ or 10 wt. $\% \quad \alpha-S i C$ under low-temperature two-stage heat treatment have high performance properties $(K C U=$ $5.6 \div 6.0 \mathrm{~kJ} / \mathrm{m}^{2} ; H V=9.4 \div 11.5 \mathrm{GPa} ; K_{1 C}$ $=3.43 \div 12.0 \mathrm{MPa} \cdot \mathrm{m}^{1 / 2}$ ) and can be used as the basis for the development of impact-resistant construction elements.

\section{References}

1. Ian G.Crouch, The Science of Armour Materials, Woodhead Publishing, Duxford (2016).

2. S.V.Zhitnyuk, A.A.Evteev, G.V.Polatov et al., Adv. Chem. Chem. Techn., 28, 157 (2014).

3. R.F. Patent 2169712 (2001).

4. U.S. Patent 7465687 (2015).

5. V.M.F.Marques, D.U.Tulyaganov, S.Agathopoulos et al., J. Eur. Ceram. Soc., 26, 2503 (2006).

6. V.A.Rozenenkova, S.S.Solntsev, Nina Mironova-Ulmane, S.V.Gavrilov, Glass Ceram., 73, 26 (2017).

7. L.R.Vishnyakov, A.V.Mazna, A.V.Neshpor, V.A.Kokhanii, Strength Mater., 6, 152 (2004).

8. M.Nader, F.Aldinger, M.J.Hoffmann, $J$. Mater.Sci., 34, 1197 (1999).

9. K.A.Weidenmann, G.Rixecker, F.Aldinger, $J$. Eur.Ceram.Soc., 26, 2453 (2006).

10. R.Yilmaz, R.Taylor, J. Mater. Scie., 42, 763 (2007).

11. O.Savvova, O.Babich, G.Voronov, S.Ryabinin, Strength Mater., 3, 167 ( 2017).

12. Canter C.Barry, Ceramic Materials: Science and Springer, New York (2007).

13. O.Savvova, L.Bragina, G.Voronov et al., Chem.Chem. Techn., 11, 214 (2017).

14. O.V.Savvova, S.M Logvinckov, O.V.Babich, A.R.Zdoric, The Issues Chem. Chem. Techn., 3, 96 (2018). 